Published in Gothic Studies 17.2 (November 2015): 1-14.

\title{
Zombie Terrorism in an Age of Global Gothic
}

\author{
Justin D Edwards
}

\begin{abstract}
With reference to films such as The Terror Experiment (2010) and Osombie (2012), this paper explores the figure of the zombie terrorist, a collectively othered group that is visually identifiable as 'not us' and can be slaughtered with impunity. In cinematic treatments, the zombie terrorist operates within a collectivity of zombies, erasing the possibility of individuality when the transformation from human to zombie takes place. The zombie terrorist signifies otherness in relation to selfhood, and is characterized by a mind/body split. Emerging from the grave in the archetypal zombie primal scene, this reanimated corpse is undead in its animate corporeality coupled with a loss of all mental faculties. The erasure of individual identity and memory along with broader human characteristics such as empathy or willpower coincides with the zombie terrorist's physical movement and action.
\end{abstract}

Keywords: zombies, terrorism, war, global Gothic, otherness

On September 16, 2012, MilitaryTimes reported that a security firm HALO

Corporation based in California had announced a counter-terrorism training program in which zombies would be under attack. The article explained how the 2012 Counter-Terrorism Summit (October 29-November 2) would incorporate training to fight the undead during its gathering of 1,000 military personnel, law enforcement officials, medical experts and government workers on Paradise Point island in San Diego. The 'Zombie Apocalypse' scenario was meant to, according to organizers, underscore the importance of being prepared for major emergencies, natural disasters and pandemics. Fictional zombies would be used to drive home the message that 'Americans must be ready for any emergency - even the kind that, hypothetically, could stem from a brain-eating virus pandemic'. In playful fashion, the article reminds us that 'for the record: Zombies are not real' but goes on to say that the Zombie Apocalypse will be a whimsical take on very real threats posed by terrorists who seek to use chemical weapons to engender a pandemic medical nightmare. 'They [the delegates] are going to see a lot of stuff going down,' the HALO president Brad 
Baker said, 'it is a Hollywood production'.

War games linking terrorists and zombies tap into popular cultural productions from video games like Terrorist Zombies to mashups of Homeland (2011-) and Walking Dead (2010-) - making zombies the 'real' terrorists - to films such as Planet Terror (2007), The Terror Experiment (2010) and Osombie (2012). ${ }^{2}$ Like the Nazi zombies of Zombies of War (2007) or Dead Snow (2009), the zombie terrorist comprises a collectively othered group that is visually identifiable as 'not us' and can be slaughtered with impunity. In cinematic treatments, the zombie terrorist operates within a collectivity of zombies, erasing the possibility of individuality when the transformation from human to zombie takes place. Thus, the zombie terrorist signifies otherness in relation to selfhood, and is characterized by a mind/body split. Emerging from the grave in the archetypal zombie primal scene, this reanimated corpse is undead in its animate corporeality coupled with a loss of all mental faculties. The erasure of individual identity and memory along with broader human characteristics such as empathy or willpower coincides with the zombie terrorist's physical movement and action: he cannot create or nurture anything so he is destructive.

The ideology linking zombies and terrorists relies on a paradigm of nonthought and non-being. Zombies and terrorists are fixed in set patterns of behavior, and when terrorism is characterized as irrational or mindless the politically-motivated grievances that lie behind the acts of terror are erased as incomprehensible and inexplicable. The zombie terrorist must be seen as mindless, lacking autonomous thought, and defined by his body: the suicide bomber and the brain-eating undead collapse into each other like the flesh that folds into the bones of the rotting corpse. Free will is negated. The zombie terrorist is controlled by a sorcerer-like demi-God; the gothic figure has been infected by a fundamentalist contagion, a monster who spreads infectious 'disease' through its dangerous and contagious bite and consumes its way through the human population.

Films such as Osombie and The Terror Experiment allow us to interrogate the ideological underpinnings of the zombie terrorist in an 'age of global gothic', a post 9/11 context defined by global terror/ism, the collapse of blocs and borders, the spectres of super-states and transnational forms of Empire. ${ }^{3}$ The mobility of people, money, arms, violence and political movements arises alongside the multidirectional cultural and economic flows of a fluid modernity that characterizes contemporary globalization. ${ }^{4}$ In this, the zombie terrorist reflects fears about the decentring of 
power; he is a global gothic figure who reveals anxiety about international terrorism and how oppositional movements challenging the powerful hegemonic discourses of the free market and neo-liberal ideologies must be contained and eradicated. Indeed, gothic conventions often locate terror as occurring 'out there'; its position is elsewhere, outside the self, and displaced from the homely and secure domestic place of 'here'. The terrorist challenges this suppression: he or she is not limited to the boundaries of a particular region and is a reminder that the terror of terrorism occurs across fluid and permeable borders, a potential contagion that threatens the security of the homely land. Put simply, terrorism forces us to recognize that 'elsewhere' is 'here', not only because the formulation of the distinction was always located in the privileged site of power but also because we can no longer refuse to see the shadows we have cast. ${ }^{5}$ It is within this context that the zombie terrorist emerges from the grave to imbue the terrorist with a zombified non-being and non-thought that pushes legitimate grievances back into the shadows and props up the hegemonic discourses of free will, free markets and neo-liberal ideologies.

The zombie terrorist is part of a long trajectory of changing signification in which the zombie can be traced and interrogated as a foil for human society. In this, the human-zombie-terrorist configuration can be conceptualized as part of a continuum as well as oppositional poles in a binary, and follows the US conventions of the zombie narrative in which zombification operates within a collectivity of undead bodies and erases the possibility of individuality when the transformation from life to undeath takes place. Here the zombie terrorist is used to signify Otherness in relation to human Selfhood, resisting the move toward the more sympathetic zombie in Romero's Land of the Dead (in which zombies lie in sharp contrast to the distinctly evil humans) or zomromcoms such as Jonathan Levine's Warm Bodies (in which zombies make good boyfriends) (Schroder 9-10). ${ }^{6}$ The zombie terrorist retains its monstrous Otherness and maintains a distant proximity to the liberal humanist ideas of Selfhood. ${ }^{7}$

Positioning the zombie terrorist within this taxonomy of zombies is significant. For in an era of globalization - an age of global gothic - the world system can confront and destroy any visible antagonism. The powerful global technostructure faces down anything that is seen to be a threat. But the technostructure of globalization has no paradigm or precedent through which such concepts as 'enemy' or 'war on terror' can be conceived and expressed. Contemporary terrorism is truly 
global: the IRA, ETA and the suicide bombings in Tel Aviv and Jerusalem are national and regional conflicts over territory and political sovereignty. In the case of the attack on the Twin Towers, the specters of terrorism produced by the body-asweapon must be reconfigured and rearticulated in order to pin down and capture the illusiveness of this new type of global terrorist. This engenders a transference whereby the illusive terrorist is defined in terms of citizenship, nationality, race, ethnicity or religion; he is then translated into specific geographical coordinates where he can be found, attacked and destroyed. Efforts are thus made to focus the conflict in order to create the delusion of a visible confrontation and a solution based on force of a 'Desert Storm'. Yet the annihilation of the WTC is not only a material attack. It is also a symbolic event that plays out the symbolic destruction of a world system of financial and economic power, the technostructure of a global Empire. 'Cruel and indifferent as it may sound', writes Žižek, 'we should also, now more than ever, bear in mind that the actual effect of these bombings [of the WTC] is much more symbolic than real ${ }^{8}$. Striking at the heart of global dominance, within this symbolic terrain, there can be no similar response, no equivalent counterattack, no absolute sign through which the so-called 'war on terror' can be won. One can imagine nothing comparable that can be destroyed with the same symbolic currency. ${ }^{9}$

But the zombie terrorist is not only a visual response to the crisis of what is feared to be a spectral presence, a violent and mysterious form of formless terror that stalks us from the shadows, unknown and unseen. By turning the body into a weapon, the suicide-terrorist transforms death itself into an absolute weapon in a system of globalization that operates on the exclusion of death, 'a system whose ideal is an ideal of zero deaths'. ${ }^{10}$ Indeed, within an era of globalization that is driven by technomedical-finance, death is failure: the dead cannot participate in the consumption that is necessary to feed the global system. But if ground zero is no longer a place of zero deaths, then nor is it a place where the corpses of the suicide attackers can be laid to rest. This is because the reality of the virtual is the space of the global, a space that exists on the screen, the network, the digital, and the dominance of a dimensionless space-time. Power is located in the dominance over the reality of the virtual, and when terrorism dominates our screens and our networks it lives on. In this, the suicide attacks on the WTC are part of a continuum in which the deaths of the pilots move seamlessly into the powerful reality of our virtual world. How many screens have broadcast the events of 9/11? How many digital networks have disseminated the 
images? How many times have the events been played and re-played over and over again on our televisions, our PCs, our laptops? It is in this realm of the virtually real the symbolic realm of screens, networks and images - that the suicide attackers will always remain undead.

The screen has the power to broadcast death, but it also has the power to suppress it. The release of several video recordings of Osama bin Laden between 2002 and 2011 were thought, by some people, to have been recorded before his socalled 'death' in early 2002 of kidney failure. ${ }^{11}$ Other reports claimed that the person in the videos was a bin Laden look-alike, and that he had been killed in Tora Bora soon after the US-led invasion of Afghanistan. If we are to entertain either of these theories, then we must conceptualize bin Laden as speaking from the dead - as undead - a zombified form that returns from the dead and is revealed to us on our screens. How many times can he die? Several, it would seem. This is particularly striking in terms of the taxonomy of 'deatherism', which comprises a myriad of reports asserting the death of bin Laden alongside counter reports that he remains alive. From this perspective, it is appropriate that President Obama announced the sea burial of bin Laden the day after the start of Zombie Awareness Month. ${ }^{12}$

The screen is also the space where representations of terrorism are constantly controlled and yet always uncontrollable. Early in a film that conflates terrorism with jihadists and zombies, Osombie depicts Afghanis broadcasting a bunker-based video calling for people to fight the 'infidels' in the name of God and to seek revenge for the attack on Osama bin Laden. But, as this video later reveals, bin Laden is not dead: he is undead. Images of him are broadcast to the world in his new zombified form, complete with rotting flesh, bulging eyes, untamed beard and soiled Afghani turban. The video is made with a small hand-held camera, a rudimentary form of technology that is consistent with representations of religious fanaticism as pre-modern and lacking in, or sometimes resistant to, advanced technologies. Yet this also mirrors the absence of technology in capturing bin Laden's death, inspiring the very conspiracy theories that propel forward the narrative thrust of Osombie. After all, it is the lack of video footage of the body and the funeral, the lack of pictures of the corpse and the lack of knowledge surrounding the sea burial (the suppression of GPS coordinates), that have perpetuated the skepticism about what at least one journalist has referred to as the 'newest death of OBL'. Reporting on the 'occurrences and coincidences' surrounding bin Laden's death and burial in a 2011 article in The Washington Post, 
Sarah Anne Hughes writes that 'conspiracy theories are being formulated about the more ambiguous aspects of bin Laden's death. Why isn't there a photograph of bin Laden's body? Was he actually buried at sea?' And, if so, where are the images? Where was he buried $?^{13}$

'Bin Laden Will Die Again', announces Osombie's tagline, promoting a movie plot that focuses on a squad of Special Forces soldiers in Afghanistan who are fighting to suppress a rampant zombie outbreak. As part of their operation, they stumble upon an American civilian, Dusty, who is searching for her crazy brother, Derek, a conspiracy theorist who is convinced that Osama bin Laden is still alive, despite reports of having been buried at sea. Of course it turns out that Derek is not so crazy after all: bin Laden has returned from his watery grave and is part of an army of zombie terrorists. Once the glassy-eyed, flesh-eating Osama emerges, the characters have to move quickly to stop these classically slow zombies from building a powerful army of zombie terrorists. And as the Americans trek to northern Afghanistan, they are faced with a growing zombie apocalypse and they must destroy the root of the zombie insurgency before the infection goes global: bin Laden must die again.

In Osombie the warfare of these zombie terrorists is premodern. They do not use the advanced technology of automatic weapons, explosives or chemical agents; instead, they attack - usually in groups - by biting the flesh of the living or infecting the soldiers with bodily fluids, so that open wounds, blood and even saliva are threats to the troops. From this perspective, it is possible to read the film as an example of rhetorical counter-terrorism, for its visual and verbal language rely on that of the Gothic discourse of horror, especially when horror manifests itself as an entity with teeth (the zombie bite) - a zone of contact between the individual and the horror which can consume, absorb the individual. In Gothic horror, the sites where 'terror' and 'horror' reach their climax are frequently related to the practices of consumption and cannibalism associated with vampirism or zombification: the dead can no longer consume, but the undead can. In Osombie, the zombie terrorists are consuming cannibals, identified as such by their open mouths and protruding teeth; these are the real cannibals, in the zombified figurative sense, who perpetuate terror, whose image, complete with voracious mouths, is associated with a mindless horde who lack cognition - unable to think for themselves - but terrorize through a collective form of consumption that feeds off human flesh. In this, the film joins terrorism with 
zombification and cannibalism in the context of a valorized language, a semiotics for comprehending this particular horror, and a stimulus for a response to it.

Dressed like bin Laden, these zombie terrorists are armed only with their bodies. As the walking dead, they mirror the suicide bomber - the 'smart bomb' of the poor and disenfranchised - whose bodies are strategic threats to life when faced with the heavily militarized weapons of the Special Forces unit. In fact, within the narrative of Osombie, the zombies are by-products of militarized capabilities that include complex biological weapons, namely 'Godsmack', a chemical agent that was meant to infect the water supply and thus force the Afghani militants out of their bunker hideouts in the mountains of Tora Bora. However, its misuse and abuse - the mixing of Godsmack with other chemicals by coalition partners - created a contagion that led to 'biological mutations', the undead. In a crucial scene in the film, the soldiers discuss how some 'Afghani extremists' intentionally consume 'Godsmack' in order to join the fight against the occupation forces in Afghanistan. When one of the soldiers says 'but that doesn't make sense', his colleague shuts down the conversion with a rhetorical question: 'when has terrorism ever made sense?'

What does it mean to dismiss terrorism as not making sense? It undermines the politically charged reasons for a terrorist attack and shields us from 'thinking too hard about what brought this about' ${ }^{14}$ If it does not make sense, then it cannot be understood; it is beyond logic and reason, and can be dismissed as nonsensical and mad. This relegates terrorism to a darkness that is juxtaposed to an enlightened perspective and undermines its political position, making its reasons worthless because there are, in fact, no reasons at all. Lacking reason and rationality paves the way for a slippage that associates terrorists with zombification. By casting terrorists as zombies, these figures are not only relegated to the margins of a Western ontology; they are completely outside of, and potentially antithetical, to an hegemony of 'common sense'. After all, the zombie lacks reason and is conceptualized within the Cartesian ontology of a mind/body split. Lacking in mental faculties, the zombie and the terrorist are pure body - a threatening corporeality that is analogous to the suicide bomber - and divorced from a catalogue of distinctly 'human' but conceptually unstable attributes such as mind, soul, spirit, free will, identity, personality, consciousness, speech, and even speed of movement. This corporeal shell, this empty vessel, becomes a 'drone' that provides power in a seemingly dehumanizing terrorist system, and in Osombie the zombie terrorist is a mindless flesh-eating monster that 
spreads its infectious 'disease' through its dangerous and contagious bite and consumes its way through the human population. Once these zombie terrorists are infected by Godsmack, they become wholly unaware of what they are doing and operate on pure instinct. Throughout the film, the zombie terrorist is both pitiful and a powerful threat to the human, and is always conceptualized in terms of a fundamental separation between mind and body. Thus, it can be slaughtered with impunity.

By conflating the incomprehensible terrorist with the brain-dead zombie, the cultural unease that is symptomatic of terrorism can be contained. For in post-9/11 times, the walking dead becomes a metonym of the system of racism, detention and torture that sustains the ideology of the 'just war'; or as Judith Butler puts it an American context, the US acts of violence 'are justified in the name of self-defense, but also by a noble cause, namely, the rooting out of terrorism. [...] Our own acts are not considered terrorist. [...] In order to condemn these acts as inexhaustible, absolutely wrong, in order to sustain the affective structure in which we are, on the one hand, victimized and, on the other, engaged in a righteous cause of rooting out terror, we have to begin the story with the experience of violence we have suffered' (6). If the narrative begins in this way, then it is not necessary to ask larger questions about why 9/11 took place. Questions do not need to be asked about the impact of American imperialism or the North Atlantic Empire of globalization that brutally dominates other hemispheres, regions and nations. Moreover, by identifying victimization as the beginning of the narrative, then the zombie terrorist can also be seen as a tool to prophesy the possible destruction of global powers. The potential apocalyptic epidemics represented in Osombie (if these terrorists are not confined to the Afghani borders) warns of the possible consequences of a decaying Empire and how quickly an imperial power might be infected and reduced to pre-modern conditions as a consequence of social rage in the age of globalization. Even Osombie's cinematic aesthetics, in which the bodies of zombies are brutalized and their blood splashes onto the camera lens, suggests that 'we' are threatened by our close proximity to the materiality of contagion which is often associated with shots of dark, decaying bodies. ${ }^{15}$

The zombie terrorist of The Terror Experiment is a different beast. In a sense, the plot revolves around a terrorist attack that tries to expose the dark side of governmental preparedness, military secrecy, chemical and biological weaponry and the US curtailing of civil liberties. Here, the so-called war on terror has led to forms 
of zombification in which government workers are forced to sit behind cubicles and work unquestioningly in front of computer screens while the American military industrial complex uses deceit and subterfuge to thwart international law and the Geneva Convention. The film opens with the image of a former US soldier who has returned from the battlefields of Afghanistan and Iraq uttering the only good dialogue in the entire film - a botched quote from Henry David Thoreau's 'Resistance to Civil Government' (1849) - 'The government does not keep the people free'. Proclaiming that he is willing to die so 'we can take back this country', he insists he is a patriot, not a terrorist, and that he seeks to 'expose the truth so people can be free'. We soon discover that he is a key figure in a political group called the Concerned Citizens Alliance (C.C.A) that has organized a series of simultaneous attacks on Federal Buildings across the United States. The film, though, focuses on one of these attacks, the one orchestrated by the former soldier and 'patriot', as he sets off an explosion that rocks a Federal Building in Lafayette and unleashes a toxic gas throughout the ventilation system. His aim is to expose the US government's secret chemical weapon, a psychotropic biological agent that attacks the adrenal system and causes the individual to become inhumanly aggressive with an uncontrollable urge to kill every person they meet. What the scriptwriters decided to blandly call 'The Infected' lose their minds and join the race of undead, spreading an infectious virus through the blood and saliva that oozes from the wounds of their decayed bodies.

Interestingly, in The Terror Experiment the zombie becomes a cipher for depicting two distinct kinds of terrorism in the United States: the domestic form of terrorism that is exemplified in the 1995 Oklahoma City bombing, and the external acts of terrorism demonstrated in the 9/11 attacks on the WTC and the Pentagon (both of which are often cited as the two most destructive acts of terrorism in US history). In fact, the spectre of 9/11 pervades the film in its references, aesthetics and plot. When the bomb rips through the building, the staff panic and one character even announces that the building will collapse like the Twin Towers. Moreover, because the bomb explodes in the middle of the building, those who are above the sixth floor are trapped; they cannot descend to the ground floor, and have nowhere to go but up the stairs or to jump from the upper floors. The images of firemen arriving to rescue those trapped in the building replicate the heroic, though ultimately fatal, stories of the fire crews entering the imploding W.T.C. And as the released gas morphs into dust and smoke, the hand-held camera shots duplicate the chaotic debris that filled the 
streets of lower Manhattan on 9/11. But the most striking echo of $9 / 11$ is the imminent collapse of the building and the external images of the W.T.C falling are dramatized from inside the building: those trapped inside - the non-infected - are aware that the building will detonate within six hours, killing everyone and everything, to ensure the contagion will be contained. As the clock ticks down its final minutes, the two main characters - Cale and Mandy - hold each other in their arms and attach themselves to a fire hose before jumping from an upper floor. This scene echoes the image of the Falling Man and the impossible decision he, and others (often holding hands), made to jump from the upper floors of the W.T.C. But in this movie version, Cale and Mandy are, quite miraculously, saved just before the building falls.

How do we read the reiteration of 9/11 imagery in this film? And what do we make of the representations linking terrorism to zombification? One way to address these questions is to reflect on the creative acts of transmutations and associative links that are required to process historical acts of violence by filtering them through a series of chronological orderings whereby selected information is dramatized within a coherent narrative structure. Inevitably, interpretive structures become grafted onto the events through hermeneutic and proairetic codes that foreground conflicts, tensions, resolutions and ethical positions. The ideological implications of this process are clear: what is emphasized, what is erased and what is implied will engender the attribution of meaning and significance to the events within the historical and political context. The contextual field cannot be divorced from the significance that is attached to the re-presentation of the narrative. The repetition of 9/11 narratives is a marked example of this, particularly because the text of the narrative is both inscribed on the pages of history books and represented in the visual texts of photography, video and digital media. It is in the visual realm, argues Susan Sontag, that 'something becomes real' to 'those who are elsewhere, following it as "news". She continues,

But a catastrophe that is experienced will often seem eerily like its representation. The attack on the World Trade Center on September 11 2001, was described as "unreal," "surreal," "like a movie," in many of the first accounts of those who escaped from the towers or watched from nearby. (After four decades of big-budget Hollywood disaster films, "It felt like a 
movie" seems to have displaced the way survivors of a catastrophe used to express the short-term unassimilability of what they had gone through: "It felt like a dream"). ${ }^{16}$

Here the creative acts of transmutations and associative links disrupt narrative chronology in the perceived chain of events - its very causality - as the movie-like event becomes integrated into the movies. This enables us to see with double vision, or multiple visions, as the evolution from violence into a coherent narrative occurs alongside the devolution of an already unreal (movie-like) event of violence and death into the cinematic realm of the unreal and the undead. Not only does this blur fact from fiction, but it also calls attention to the subject's position in relation to the proximity of the violence: those trapped in the stair-well of the W.T.C. or those jumping from the $40^{\text {th }}$ floor of the building do not experience 9/11 like it is a movie. The relationship between inside and outside, internal and external, experience and witness are paramount to any associative links that are translated into the hermeneutic code of the event. Yet to a large extent those on the inside - those who experienced it internally - did not survive to contribute to this narrative and, as a result, the absence is filled in by invoking the voices of the dead, a representation that necessitates the movement from the dead to the undead. The Terror Experiment exemplifies this process, for the events of 9/11 are replayed from the inside: we follow the stories of those trapped in the building, moving from the living characters who are still healthy to the infecteds on $6^{\text {th }}$ floor and below. The infecteds are the already-dead, a form of zombification that skips the stages of death and burial, and moves directly from the living to the undead. Yet the internal perspective on the event also performs the associative act of bringing people back from the dead, for we cannot help but think of these as embodied images of those people who died in the W.T.C. Such connections add drama and meaning by making the film appear to resonate throughout the historical moment by re-producing past events, and giving a voice to the deceased, making possible a meaningful interpretation of the whole field of facts and events that is not just seen from the outside 'like a movie'. The movie makes it 'real'. ${ }^{17}$

Enter the zombie terrorist. In The Terror Experiment, he moves like a sleepwalker, a somnambulist who strides in a trance-like state, as if he has fallen under the power of a sorcerer. In this state, he becomes the suicide bomber: he ignites the chemical bomb knowing he will become an infected, and he calmly accepts his fate in 
joining the ranks of the undead. Within the symbolic logic of the film, the suicide bomber is already zombified. He is all body and no mind - his only power rests in the body that hosts the weapon - and he is seen to be driven by forces that, as the American soldier in Osombie says, 'don't make sense'. Moreover, like the Godsmack of Osombie, the gas unleashed by the suicide bomber (the chemical agent called M. K. Ultra) does not lead to death; it leads to undeath. The zombie produces other zombies.

The unleashed gas is, in a sense, collateral damage, for it is produced by the U.S. military and must be contained before the infection spreads. Here, those who have succumbed to the rage-virus and those yet to be infected must try to survive without the safety of social institutions. In fact, the very social institutions that these civil servants were working to preserve are no longer there to protect them: the governing body overseeing the outbreak has become a threat to the survival of its loyal workers, as the officials will simply kill all that remains inside the building. From this perspective, The Terror Experiment echoes the theme of social decay that is present in so many 'zombie virus' films - from David Cronenberg's Rabid (1977) to Danny Boyle's 28 Days Later (2002) and many more - in which the degeneration of social structures has direct parallels to the social unrest of insurgences, riots, uprisings and terrorism. In many zombie texts, the undead try to physically enter a safe space; they must be kept at bay. But in the zombie virus narrative the contagion threatens to break out of an unsafe space; it is a potential outbreak that is ubiquitous and must be contained. The building needs to be placed under quarantine so that nobody can exit or enter until the air-born agent is neutralized. ${ }^{18}$

We might also read the link between zombification and contagion, whether in the form of an air-born gas or contaminated water, as reflecting a fear of the individual being subsumed into the collective. After all, an air-born contagion bypasses the zombie bite, which is an interaction between the bodies of two individuals (or former individuals), circumventing one-on-one interface and contact. The invisible and anonymous infection is something that transforms the human in seconds and employs the thematics of contamination to articulate a cultural interest in the biological permutation of the human. Because this narrative catalogues instances of zombification rather than death, it represents the deviation from a previous and established self through the modification of identity, memory and behaviour that is at stake when the zombie gas enters and takes hold of the human body. But unlike 
Osombie, in The Terror Experiment, the zombie terrorist's Otherness is not inscribed on his body. As in the case of Timothy McVeigh, another Gulf War veteran, the threat is not visually identifiable; he is not marked by the categories of 'us' and 'them' but walks among 'us', unseen and undetected. He is the 'home grown' terrorist who threatens to move the familiar domestic place into a space of unhomely chaos. The invisibility of the zombie host is mirrored in the invisibility of the toxic gas - the unseen spread of the virus - that infects the community and spreads zombification. This is, in turn, transferred into a symbolic register in which the disclosure of government secrets is on the verge of leaking out, spreading to the wider community. Contagion and the spread of information are intertwined, as the dissemination of information moves like a virus, and this is underscored by the vulnerability of the building, which must be destroyed so the infection/information can be controlled. Here, we see the cracks in the façade of a homely nation that is meant to be based on justice and ethical imperatives, a domestic place that protects its citizens, an ideology that must be maintained at all costs. For the possible dissemination of this toxic information will move far beyond the nation's borders, as the flow of international media is poised to broadcast the US-funded military programme of biological and chemical weapons and expose a breach of international law. ${ }^{19}$

Media contagion is often defined as part of a vocabulary of loss that is linked to suicide, grief and ethics. In the context of a global network of mass media that includes conventional communications alongside social media, weblogs and other techno-global systems, the anxiety of a viral spread of information increases exponentially. Interactions are embedded in a network of communication that spans the globe through new media, allowing information to spread from one person to another by both regulated and unregulated sets of intermediary ties. This breeds a fear of media contagion disseminating the classified information of state-funded chemical and biological weapons as, in both films, the military programmes of psychotropic drugs need to be kept under raps: the leaked information of Godsmack or M. K. Ultra could call into question the ethics of US military interventions into foreign nations. This is paralleled by another anxiety: the fear of a viral spread of global terror through a contagious media that presents the suicide bomber as warrior, hero or martyr. For when a suicide bombing goes viral, the landscapes of corporate and personalized media ecologies become increasingly threatening as a source for inspiring acts that are repeated by others, spreading terror/ism across the globe. 
By filtering a global 'war on terror' through zombification, the zombie terrorist is incorporated into the global gothic markers of otherness that attempt to neutralize threats to a neo-liberal imperialist power, threats that move fluidly between borders, nations, countries and territories. This is highly ironic, for the contagion of hyper-capitalism represents its other as an infection that will lead to global instability. Zombifying the terrorist neutralizes the threat by erasing the question of motivation. After all, the terrorist's motives, his very ontology, cannot be coopted within neoliberal forms of global capitalism: the suicide bomber is, for instance, not just a danger to the lives of those in close proximity to him; he also challenges a symbolic order that survives off of mass consumption, international networks, and global markets. Zombie terrorists are thus reduced to a single function, driven by one obsessive idea, and behave contrary to 'logic' and 'nature'. In Osombie and The Terror Experiment, we are encouraged to dis-identify with an ontology that is conflated with a monstrous figure who is unthinking, unknowing and undead. Represented as abject Other, this process of disidentification is not a productive way of advancing our understanding of a matrix of identity in which he or she is simultaneously marginalized and appropriating mainstream culture. Instead, these films problematize the concept of disidentification within a dialectic of identification and counter-identification, suggesting that our disidentification with the terrorist-aszombie is part of a symbolic system of disavowal and repudiation.

\section{Address for Correspondence}

Justin D Edwards: School of English and Languages, University of Surrey, Guildford, GU2 7XH, UK. E-mail: justin.edwards@surrey.ac.uk

Biographical information: Justin D Edwards is Professor of English at the University of Surrey. He is the author of several books, including Grotesque (2013), Mobility at Large (2012), Postcolonial Literature (2008), Understanding Jamaica Kincaid (2007), Gothic Canada: Reading the Spectre of a National Literature (2005), Gothic Passages: Racial Ambiguity and the American Gothic (2003) and Exotic Journeys: Exploring the Erotics of U.S. Travel Literature (2001). He is editor or coeditor of the following books: Technologies of the Gothic (2014), Gothic in Contemporary Popular Culture: Pop Goth (2012), Postcolonial Travel Writing: Critical Explorations (2010), Other Routes: 1500 Years of Travel Writing by Asians and Africans (2006), Downtown Canada: Writing Canadian Cities (2005). 
${ }^{1}$ MilitaryTimes:

http://www.militarytimes.com/article/20120916/NEWS/209160313/Securityfirm-hold-zombie-crisis-scenario Online May 3, 2013. Online.

2 Zombie terrorists can be found in various forms of popular culture. Examples include, but are in no way limited to, the video game Terrorist Zombies (2010), the song 'Zombie Terrorist' (2006) by the band Partyline and 'The Terrorist Zombie' paper target, manufactured by Zombie Industries, which can be used on firing ranges.

${ }^{3}$ Osombie, directed by John Lyde, Arrowstorm Entertainment, 2012; The Terror Experiment, directed by George Mendeluk, Anchor Bay Entertainment, 2010.

${ }^{4}$ See Fred Botting and Justin D Edwards, 'Theorising Globalgothic', in

Globalgothic, Glennis Byron (ed.), (Manchester: Manchester University Press, 2013), pp. 11-24.

5 Tabish Khair, The Gothic, Postcolonialism and Otherness: Ghosts from Elsewhere (Basingstoke: Palgrave, 2009), p. 173.

${ }^{6}$ Anne Schroder, 'Zombie Fictions: Possession, Consumption and Zombification in Recent Caribbean and U.S. Literature', PhD dissertation, University of Essex, 2011. pp. 9-10.

${ }^{7}$ See Terence McSweeney, 'The Land of the Dead and the Home of the Brave: Romero's Vision of a Post-9/11 America', Reframing 9/11: Film, Popular Culture and the 'War on Terror' in Jeff Birkenstein, Anna Froula and Karen Randell (eds), (London: Continuum, 2011), pp.107-16. Terence McSweeney argues that the army of zombies in Romero's Land of the Dead (2005) articulates an ambiguous vision of racial and cultural purity by suggesting that the fictional world of Romero's Fiddler's Green and post-9/11 America highlight the socio-economic protectionism and surveillance that is part of the film's critique of the 'War on Terror' and US global dominance. The collective body of the disenfranchised proletariat that surrounds the utopian enclave of Fiddler's Green, along with the outcast zombies, outnumbers the elite which employs military and technological superiority for its protection. But when the fortifications break down, the encounter between the oppressors and the oppressed stages the deconstruction of the cultural myth of American immunity, representing contamination as the only possible outcome of a forced encounter between the US and its Other.

${ }^{8}$ Slavoj Žižek, 'Welcome to the Desert of the Real!' The South Atlantic Quarterly 101.2 (Spring 2002), p. 388

${ }^{9}$ In the film World War $Z$ (2013), the so-called security wall separating Palestine from Israel is, at first, seen to be an effective prevention of zombie attack.

Justified by Israel as a way of combatting terrorism, this depiction of the wall has been criticized by some audiences as supporting Israeli apartheid policies in the region, whereas other audiences have viewed these scenes as unifying Jewish and Muslim communities against the spread of zombification.

10 Jean Baudrillard, The Spirit of Terrorism, Translated by Chris Turner (London: Verso, 2002), p. 16.

${ }^{11}$ Jeffrey Goldberg, 'The Warp-Speed Rise of "Deatherism"', The Atlantic May 2, 2011, http://www.theatlantic.com/international/archive/2011/05/the-warpspeed-rise-of-deatherism/238187/ Online.

12 The killing of Osama bin Laden is also incorporated into the plot of Robert Rodriguez's film Planet Terror (2007). Here the zombified figure of Lt. Muldoon 
Muldoon, a US veteran returned from Afghanistan, explains how he killed OBL just before he and his men were infected with DC2, an American chemical weapon that turns people into zombies.

13 Sarah Anne Hughes, 'Conspiracy Theories Surrounding Osama bin Laden's Death', The Washington Post, May 2, 2011.

14 Judith Butler, Precarious Life: The Powers of Mourning and Violence (London: Verso, 2004), p. 2. All subsequent references to this edition are given in parentheses in the text.

15 See Anna Froula, 'Prolepsis and the "'War on Terror": Zombie Pathology and the Culture of Fear in 28 Days Later...'. Reframing 9/11: Film, Popular Culture and the 'War on Terror', Jeff Birkenstein, Anna Froula and Karen Randell (eds), (London: Continuum, 2011), 206. Froula offers an interesting reading of the aesthetics of Danny Boyle's 28 Days Later (2002): she argues that the film's accelerated pace and the contagion, often through dark bodies, warns of how apocalyptic epidemics reflect the inevitable consequences of a colonial power and how quickly even a former centre of Empire like London can be reduced to 'third world' city.

${ }^{16}$ Susan Sontag, Regarding the Pain of Others (New York: Picador, 2004), p. 19.

${ }^{17}$ Another example of the blurring of fact and fiction is identified by Jeffery Jerome Cohen, who points out that the Centers for Disease Control in Atlanta published a graphic novella, Preparedness 101: Zombie Pandemic, which is pitched as 'a fun new way of teaching about emergency preparedness'. See Jeffery Jerome Cohen, 'Undead (A Zombie Oriented Ontology)', Journal of the Fantastic in Arts 23.3 (2012), p. 400.

${ }^{18}$ An interesting example of this is the first installment in the Resident Evil series (2002) in which the theft of the generically engineered T-virus leads to a zombie outbreak in 'the Hive', a space that must be sealed off in an attempt to stop the spread of the outbreak and sacrificing the uninfected humans within the genetic research facility.

${ }^{19}$ An example of terrorism and the possible viral infection of media was present in May 2011 when the FBI issued a statement stating that the 'Osama bin Laden video is a virus', and explaining that 'messages claiming to include photos and videos of Osama bin Laden's death actually contain a virus that could steal personal information'. See Robert McMillan, 'Bin Laden Video is a Virus, FBI Warns', PC World, May 4, 2011.

http://www.pcworld.com/article/227039/Bin_Laden_ Video_Is_a_Virus_FBI_Warns.html. November 3, 2013. 